\title{
The Iconography of Goddess Tjenenet from the Middle Kingdom to the Late Period
}

Mina Samy Fareed*,Walid Shaikh Al Arab, Taher Abdelhamid

Faculty of Tourism and Hotels, Fayoum University, Egypt

\section{ARTICLE INFO}

Keywords:

Tjenenet

Montu

Iunit

Rettway

Tod

Armant

Medamoud.

\begin{abstract}
The Egyptian Goddess Tjenenet was a local goddess whose evidence survived from Middle Kingdom to Ptolemaic and Roman Period. She is known mainly as the divine consort of god Montu and a dweller in his chief cult centers, especially at Tod, Armant, and Medamoud. She is often represented anthropomorphically crowned either with two cow's horns with an integrated sun disk, or with a Bicornuate uterus. Considering that her worship extended over nearly three thousand years, it seems inevitable that her iconography has seen some changes. This paper aims to shed light on the principal development moments of the iconography of goddess Tjenenet by responding to the following inquiries: how far is the possibility to recognize goddess Tjenenet despite the absence of her legends? Could the various aspects of her character influence her iconography? Does the form of this goddess vary according to the role she plays or the period in which she was depicted? Is it possible to consider the representations of Tjenenet as a measure of dating? Therefore, this paper tries to present and clarify the personality of Tjenenet by highlighting her iconography
\end{abstract}

C2021 Faculty of Tourism and Hotels, Fayoum University All rights reserved

\section{Introduction}

The Egyptian Goddess Tjenenet 1, was a local goddess whose evidence mainly survived from the
Middle Kingdom to the Ptolemaic and Roman period. Tjenenet was first appeared ${ }^{2}$ at the village of $\operatorname{Tod}^{3}$, where

\footnotetext{
* Contact Mina Samy Fareed at: msf11@ @ayoum.edu.eg

${ }^{1}$ For further information about goddess Tjenenet, see Ch. Thiers, "Hymne à la déesse Tanent et présence latopolite sur quelques blocs d'Ermant", in: CENiM 13, 2015, pp.295-326; G. Hart, The Routledge Dictionary of Egyptian Gods and Goddesses, Second Edition, 2005, p. 182;c R. H. Wilkinson, The Complete Gods and Goddess of Ancient Egypt, Thames \& Hudson, 2003, p. 168; LGG VII, pp. 475(a) - 476(b); LÄ VI, col. 610; M. Thersia, Synkretismus in Ägyptischer Ikonographie die Göttin Tjenenet, Otto Harrassowitz, 1979

${ }^{2}$ See M. Thersia, Synkretismus in Ägyptischer Ikonographie die Göttin Tjenenet, Otto Harrassowitz, 1979, p. 6.

${ }^{3}$ Located in the 4th Nome of Upper Egypt, on the eastern bank of the Nile approximately 20 kilometers south of Luxor, the village of Tod, El-Tod or the modern Arabic name "طود" houses a main dedicated temple for god Montu in which the cult of goddess Tjenenet took place. Tod was called in the ancient Egyptian language "Drt or Drty Fे/. Meanwhile, in the ancient Greek, it was called "Touphion - Toúpıo" and in Latin "Tuphium" while in the Coptic time, it was called "тגоүт - тооүт." For more information about Tod, see G. Bonnefois, "Tod", in Redford, B. Donald (ed.), The Oxford Encyclopedia of Ancient Egypt. Vol. 3, Oxford University Press, 2001, pp. 411-412; F.
} 
hry(.t)-ib 9rt" meaning "goddess Tjenenet the one who resides at Tod". Later she took place at Armant $^{4}$, and Medamoud ${ }^{5}$. She was the consort of the prominent god, Montu ${ }^{6}$, who was a falconheaded god with increasing importance since the $11^{\text {th }}$ Dynasty at Thebes region. Both were once considered as the parents of Horus-Re the Infant ${ }^{7}$. Having radiant worship for many centuries, if not millennia, it is understandable that the representations of this goddess have seen many changes during this long period. Her manifestations could be traced only, starting from the Middle Kingdom (ca. 2030 - 1650 B.C.), precisely during the $11^{\text {th }}$ Dynasty at Tod. The earliest representation of the goddess Tjenenet depicts her in a complete human form, wearing the basic vulture-style headdress with no heademblems on the stone blocks of Montuhotep III at $\mathrm{Tod}^{8}$. By the New Kingdom (ca. $1550-1070$ B.C.), the popularity of Tjenenet grew, and her depictions can be found on temples and funerary monuments, where she was associated with different goddesses like Iunit ${ }^{9}$ and Rettawy ${ }^{10}$. Her representations have been enriched with new

Bisson de la Roque, Tôd, FIFAO 17, 1937; H. Gautheir, Dictionnaire des noms géographiques contenus dans Les texts Hiéroglyphiques VI, Le Caire, 1929, pp. 130131.

${ }^{4}$ Located in the $4^{\text {th }}$ Nome of Upper Egypt, on the western bank of the Nile approximately 20 kilometers ${ }^{4}$ south of Luxor, the village of Armant or the modern Arabic name "أرمنت houses a mainly dedicated temple for god Montu in which the cult of goddess Tjenenet took place. Armant was known in the ancient Egyptian language with ${ }^{3} \otimes$ "Iwn-šm ${ }^{\top} w$ - the Southern Iun" Meanwhile, in the ancient Greek, it was called "Hermonthis - E $\rho \mu \tilde{\omega} v \theta \imath \varsigma$ " and in Latin "Hermuntis" while in the Coptic time, it was called "EPMeNT apmane." See H. Gautheir, Dictionnaire des noms géographiques contenus dans Les textes Hiéroglyphiques I, 1929, p. 53.

5 The village of Medamoud is located within the 4th Nome of Upper Egypt, on the eastern bank of the Nile approximately 5 kilometers northeast of Karnak. The village of Medamoud or the modern Arabic name "ميدامود" housed one day a mainly dedicated temple for Montu in which the cult of goddess Tjenenet took place. It was known in the ancient Egyptian language with "M3dw." Meanwhile, in the ancient Greek, it was called

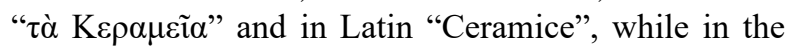
Coptic time, it was called "пєтемоүт."

${ }^{6}$ E. K. Werner, The God Montu: From the Earliest Attestations to the End of the New Kingdom, Ph. D. Dissertation, Yale University, 1985, pp. 266-268. phenotypes. She acquires new forms and obtaining her remarkable "Bicornuate uterus"11 emblem and many other head-emblems.

This paper aims to recognize and clarify the principal development moments of the iconography of goddess Tjenenet by responding to the following inquiries: how far is the possibility to recognize goddess Tjenenet despite the absence of her legends? Could the various aspects of her character influence her iconography? Does the form of this goddess vary according to the role she plays or the period in which she was depicted? Is it possible to consider the representations of Tjenenet as a measure of dating? Therefore, this paper tries to present and clarify the personality of Tjenenet by highlighting her iconography. The paper is divided chronologically into three main parts: the Middle Kingdom, the New Kingdom, and the Late Period. Each part contains her different representations, organized in different sets.

\section{Iconography}

\subsection{The Iconography of Tjenenet during the Middle Kingdom}

${ }^{7}$ See É. Driton, G. Posener, et J. Vandier, Tôd: les Inscriptions du Temple Ptolémaïque et Romain I, la salle hypostyle, textes nos 1-172, Le Caire, p. 4, pl. 1.

${ }^{8}$ F. Bisson de la Roque, Tôd, FIFAO 17, 1937, pp. 7980, fig. 32 .

${ }^{9}$ Iunit was a local goddess of mainly importance in the Theban region, precisely in the town of Armant. For more information, see $L G G$ I, pp. $190_{(a)}-192_{(b)} ; L \ddot{A}$ III, col. 212; R. H. Wilkinson, The Complete Gods and Goddess of Ancient Egypt, Thames \& Hudson, 2003, p. 150; M. el-Weshahy, "The Goddess Iwnj.t", in Association of Arab Universities For Tourism and Hospitality, JAAUTH, Vol.4. No 2, pp. 123-149.

${ }^{10}$ Rettawy appeared for the first time within the texts of the Pyramid Texts since the $5^{\text {th }}$ Dynasty, where she was assigned as the counterpart of god Re. For further readings, see $L G G \mathrm{IV}$, pp. $647_{(\mathrm{c})}-649_{(\mathrm{a})} ; L \ddot{A} \mathrm{~V}$, col. 151155; R. H. Wilkinson, The Complete Gods and Goddess of Ancient Egypt, Thames \& Hudson, 2003, p. 164; A. Enany, "Representations of the Goddess Rait-Tawy in Ancient Egypt" in Studies in the Antiquities of the Arab World 16, pp. 123-144.

${ }^{11}$ For further readings about the Bicornuate uterus, see M. Thersia, Synkretismus in Ägyptischer Ikonographie die Göttin Tjenenet, p.8; R. Barone, Anatomie comparée des mammifères domestiques, tome 4: Splanchnotomie II. Appareil uro-génital, ed. Vigot, 1990. p. 322-323; Ph. Collombert, "Quelques Précisions sur la Lecture et la Signification du Mot Pö, in $R D E 46,1995$, pp. 205208. 
The earliest known representation for goddess

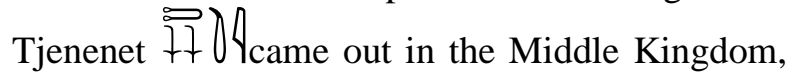
as, at least, no evidence of her can be traced in the Old Kingdom (ca. 2647 - 2150 B.C.). Tjenenet appeared for the first time during the reign of king Montuhotep III on few blocks of limestone, which were found at Tod. ${ }^{12}$ These documents are considered the only pictorial depictions of goddess Tjenenet during the Middle Kingdom. Only one representation for goddess Tjenenet in complete human form has survived

Four pictorial representations can be traced on the block-stones which were unearthed by Fernand Bisson de la Roque in 1937, as relics of the Middle Kingdom temple of Montu at Tod. Two of these block-stones (JE 66337, and JE 66333) ${ }^{13}$ have only traces of goddess Tjenenet, wearing the vulturestyle headdress (fig. 1, pl. 1) with no heademblems.

\section{Fig. 1}

Head of goddess Tjenenet.

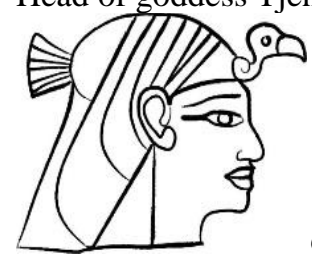

@ Mina Freed cliché

One survived representation portrays her in a complete human form (fig. 2, pl. 2) ${ }^{14}$, she is standing in adoring attitude, wearing the vulturestyle headdress, and a long, close-fitting tunic, and holding within her right hand three "enh" signs

Fig 2

Goddess Tjenenet in adoring attitude.

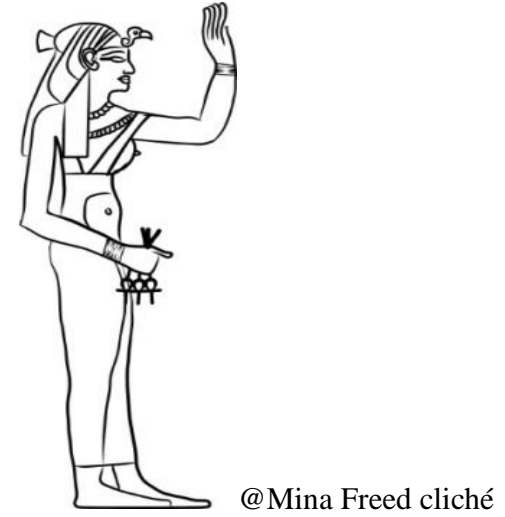

On one block of stone (E. 15144) ${ }^{15}$ which is housed nowadays in Musée du Louvre, department of Egyptian Antiquities, Tjenenet is depicted with the same features, holding the " $w 3 s$ " scepter (fig. 3, pl. 3)

Fig 3

Tjenenet holding the "w3s" scepter.

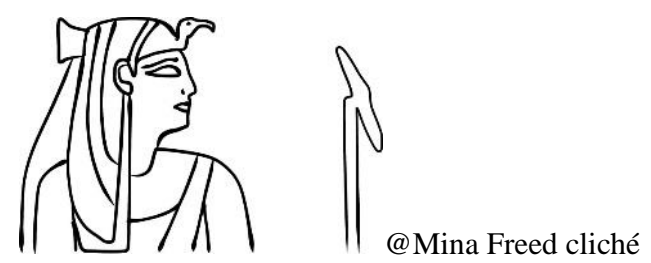

2.2. The Iconography of Tjenenet during the New Kingdom

The representations of the goddess Tjenenet in the New Kingdom have reached a new popularity level, as her fame continued to increase remarkably. This period has witnessed unprecedented blending for goddess Tjenenet, where she was merged with goddess Iunit and goddess Rettawy. Although the fact that the earliest recorded pictorial representation for the goddess Tjenenet-Rettawy Queen Hatshepsut ${ }^{16}$, there is a block of stone (UC. $14402)^{17}$ that dates to King Ahmose I, housed in

${ }^{16}$ As one of a group of deities, in a relief located on the southern side of the Red Chapel at Karnak Temples; see Fr. Burgos, Fr. Larché, La Chapelle Rouge. Le sanctuaire de barque d'Hatshepsout, I, Paris, 2006, p. 253; P. Lacau, H. Chevrier, M.-A. Bonhême, Une chapelle d'Hatshepsout à Karnak, I, Le Caire, 1977, p.325.

${ }^{17}$ H.M Stewart, Egyptian Stelae, Reliefs, and Paintings: from the Petri Collection, part I: the New Kingdom, 1976, pl. 1, p.1. 
Petri Collection Museum, has remnants of her name.

\subsubsection{Standing, wearing the Bicornuate uterus $\uparrow^{\circ}$}

The eldest time for Tjenenet to be presented with the Bicornuate uterus emblem (fig. 4, pl. 4) came in relief on the northern wall of the Red Chapel of Queen Hatshepsut ${ }^{18}$ at Karnak temples, which dates to the $18^{\text {th }}$ Dynasty, as Tjenenet-Rettawy. She is depicted standing, with her emblem over a tripartite hair wig, fixed by a headband, and wearing a long, tight tunic, and holding the " $w 3 s$ " scepter and the " $n h$ " sign. Furthermore, as goddess Tjenenet-Rettawy, the goddess is also represented with her uterus-emblem over a tri-partite hair wig, fixed by a headband ${ }^{19}$, supporting King Thutmoses III (fig. 5, pl. 5) while his coronation by Montu.

Fig. 4

Tjenenet standing, wearing the Bicornuate uterus.

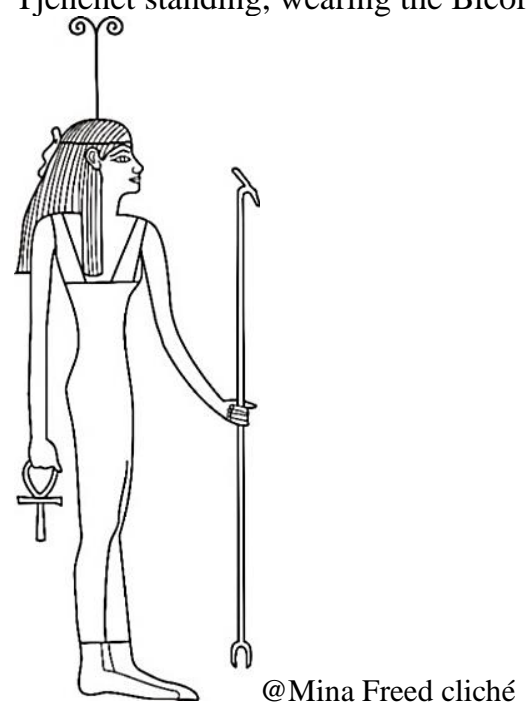

${ }^{18}$ See Fr. Burgos, Fr. Larché, op.cit, p. 116; P. Lacau, H. Chevrier, M.-A. Bonhême, op.cit, pp. 226-227.

${ }^{19}$ See K. Sethe, Urkunden der 18. Dynastie, Abteilung IV, Leipzig, 1906, p. 556; R. Lepsius, Denkmäler aus Aegypten und Aethiopien Text, III, Leipzig, 1900, p. 34. ${ }^{20}$ See W.J. Murnane, Ramesses I and the Building of the Great Hypostyle Hall Revisited, VA 10/2-3, 1997, p. 163; P. Barguet, op.cit, p. 70; A. El-Sharkawy, Der Amun-Tempel von Karnak. Die Funktion der Großen Säulenhalle, erschlossen aus der Analyse der Dekoration ihrer Innenwände, Wissenschaftliche Schriftenreihe Ägyptologie 1, Berlin, 1997, pp. 108109.

${ }^{21}$ On the eastern and the western banks of the Nile, in the $2^{\text {nd }}$ Nome of Upper Egypt, and between Kom Ombo and Edfu, the area of Gebel el-Silsila is approximately
Fig. 5

Tjenenet standing, wearing the Bicornuate uterus.

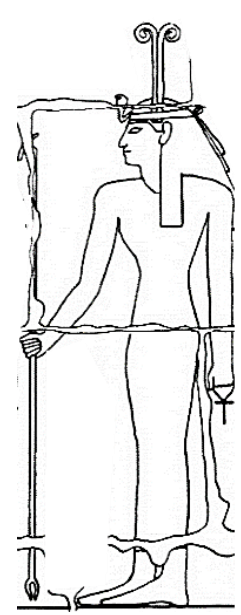

Nelson, The Great Hypostyle Hall at Karnak, OIP 106, 1981, pl. 140.

By the beginning of the $19^{\text {th }}$ Dynasty, during the reign of Ramses I, goddess Tjenenet was portrayed with the uterus-emblem ${ }^{20}$ in the presence of SobekRe and Iunit, standing (fig. 6, pl. 6), holding the "w3s" scepter and the " $n h$ " sign. On the northern wall of Ramses II's rock-cut chapel at Gebel ElSilsila $^{21}$ region, Tjenenet is depicted ${ }^{22}$ standing (fig. 7, pl. 7) between Sobek-Re and Rettawy, wearing the Bicornuate uterus as a head-emblem. Moreover, she is holding the "w3s" scepter with her left hand, while with her right hand, she is holding the " "nh" sign of life. In one relief ${ }^{23}$, dating back to Ramses III, goddess Tjenenet is represented along the Great Ennead with her unique Bicornuate uterus emblem (fig. 8, pl. 8), standing in adoring attitude and wearing a long, tight tunic.

Moreover, during the reign of Ramesses IV of the $20^{\text {th }}$, on column 48 of the Great Hypostyle Hall ${ }^{24}$,

65 kilometers north of Aswan. the area was called "Hny" meaning "the rowing place.

${ }^{22}$ I. Rosellini, I Monumenti dell' Egitto e della Nubia, Tomo III, Parte I, Pisa, 1838, p. 135, pl. XXXI (2).

${ }^{23}$ See G. Legrain, "La litanie de Ouasit ", ASAE 15, 1915, p. 278; G. Jéquier, L'architecture et la décoration dans l'ancienne Égypte 2. Les temples ramessides et saïtes, Paris, 1922, pl. 67; The Epigraphic Survey, Reliefs and Inscriptions at Karnak - Volume I. Plates 178. Ramses III's Temple within the Great Inclosure of Amon, Part I, OIP 25, 1936, pl. 56.

24 L. Christophe, "Temple d'Amon à Karnak. Les divinités des colonnes de la grande salle hypostyle et leurs épithètes", in: $B d E$ 21, 1955, p. 17. 
goddess Tjenenet (fig. 9, pl. 9) is depicted behind her husband Montu, wearing the uterus-emblem over the " $h 3 t$ " headdress with its protective cobra.

\section{Fig. 6}

Tjenenet wearing the Bicornuate uterus, supporting Thutmoses III.

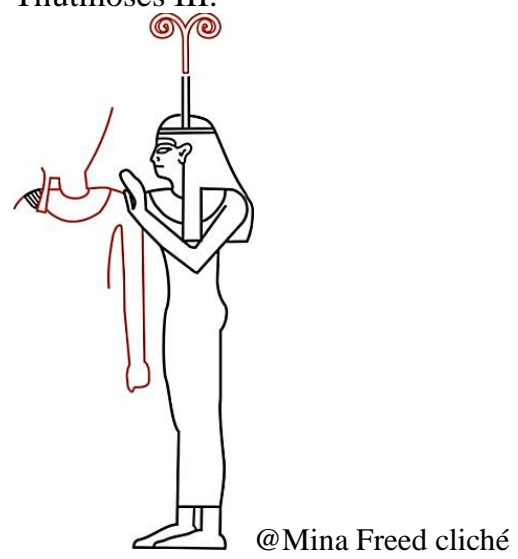

Fig. 7

Tjenenet wearing the Bicornuate uterus.

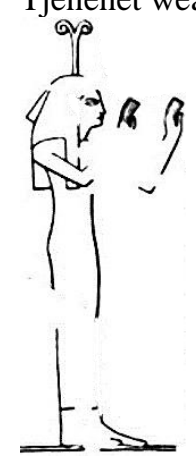

I. Rosellini, I Monumenti dell' Egitto e della Nubia III, 1838, pl. XXXI (2)

\section{Fig. 8}

Tjenenet standing in adoring attitude, wearing the Bicornuate uterus.

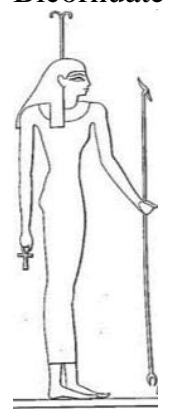

H.H Nelson, The Great Hypostyle Hall at Karnak, OIP 25, 1936, pl. 56.

${ }^{25}$ Attested during the reign of king Thutmoses III, see P. Barguet, Le Temple d'Amon-Rê à Karnak: Essai d' exégèse, le Caire, 1962, p. 164; R. Lepsius, Denkmäler
Fig 9

Tjenenet standing, supporting god Montu.

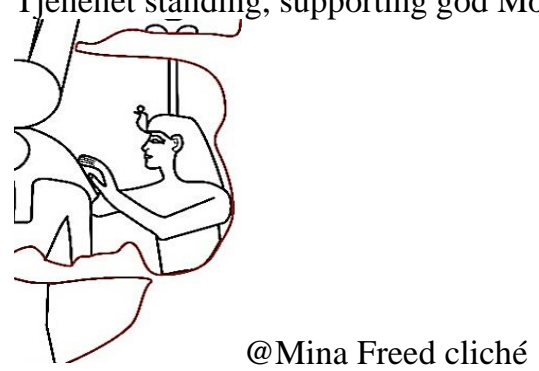

2.2.2 Enthroned, wearing the Bicornuate uterus $\Upsilon^{\top}$

On the stela of Neb-Imentet at Voronez Museum (Inv 157), which dates to the $19^{\text {th }}$ dynasty, the reign of king Ramses III, goddess Tjenenet Nefrt-nt-

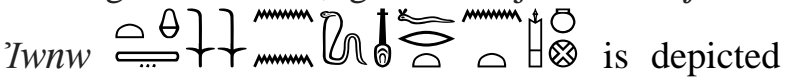
with her unique Bicornuate uterus emblem and enthroned on a low-back throne (fig. 10, pl. 10). Furthermore, she is holding the " $w 3 \underline{d}^{\prime}$ " scepter and the " $n h$ " sign.

\section{Fig 10}

Tjenenet-Nefrt-nt-'Iwnw enthroned, wearing the Bicornuate uterus.

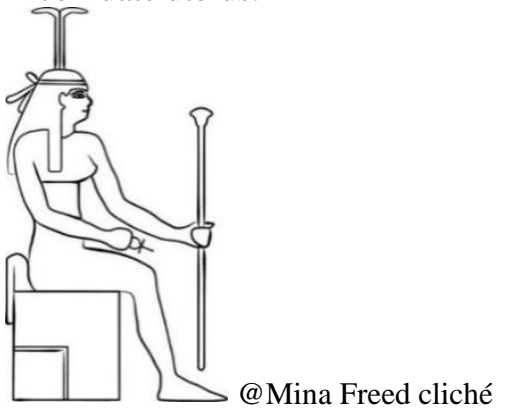

\subsubsection{Enthroned, with no head-emblems}

Starting from the $18^{\text {th }}$ Dynasty, precisely since Queen Hatshepsut to the end of the New Kingdom, goddess Tjenenet enjoyed a constant place within the Great Ennead of Karnak Temples. Tjenenet was often portrayed enthroned wearing a tri-partite hair wig and a long, tight tunic, ${ }^{25}$ (fig. 11, pl. 11) holding the "wss" scepter and the "nh" sign, or enthroned, wearing a tri-partite hair wig and a

aus Aegypten und Aethiopien Text, III, Leipzig, 1900, p. 34. 
completely covered body by a mantle ${ }^{26}$ (fig. 12 , pl. 12), holding the "w3s" scepter and the " $n h$ " sign In the $19^{\text {th }}$ Dynasty, precisely during the reign of Ramses II, goddess Tjenenet was depicted enthroned $^{27}$, within the Great Ennead (fig. 12) wearing a tri-partite hair wig and a long, closefitting tunic. Additionally, in the $20^{\text {th }}$ Dynasty, during the reign of Ramses III, goddess Tjenenet is depicted enthroned ${ }^{28}$ before a shrine-like building (fig. 13, pl. 13), wearing a tri-partite hair wig, and holding a basket, provided with the " $n h$ " sign and the "w3s" scepter

\section{Fig. 11}

Tjenenet enthroned wearing a long, tight tunic

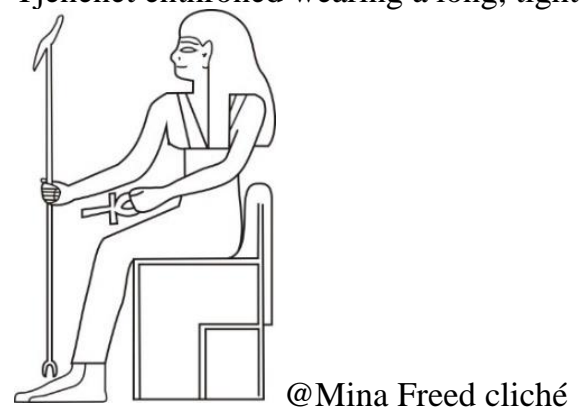

Fig. 12

Tjenenet enthroned with a mantel covering her body.

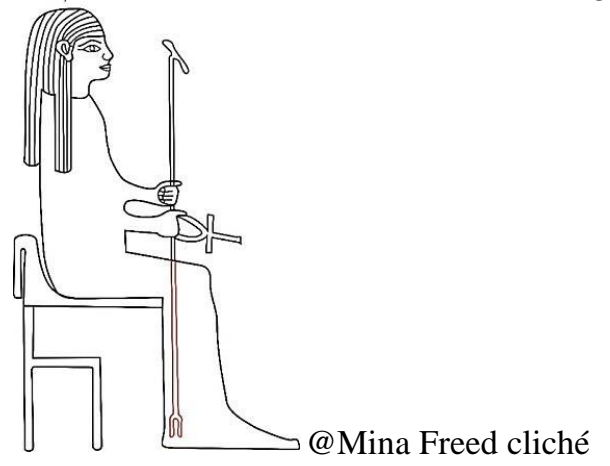

${ }^{26}$ This is considered the earliest example, dating to the reign of Queen Hatshepsut, according to the available evidences, see Fr. Burgos, Fr. Larché, La Chapelle Rouge. Le sanctuaire de barque d'Hatshepsout, I, Paris, 2006, p. 253.

${ }^{27}$ See P. Barguet, « Le temple d'Amon-Rê à Karnak. Essai d'exégèse », RAPH 21, 1962, p. 66; M. Pillet, Thèbes, Karnak et Louxor, Paris, 1928, p. 8, fig. 7; G. Legrain, Les temples de Karnak. Fragment du dernier ouvrage de Georges Legrain, Directeur des Travaux du Service des Antiquités de l'Égypte, Bruxelles, 1929, pp. 217-220, fig. 129-130.

28 The Epigraphic Survey, Medinet Habu, Volume V. The Temple Proper, Part I: The Portico, the Treasury,

\section{Fig. 13}

Tjenenet enthroned holding a basket contains the " $n h$ " sign and "wss" sceptre.

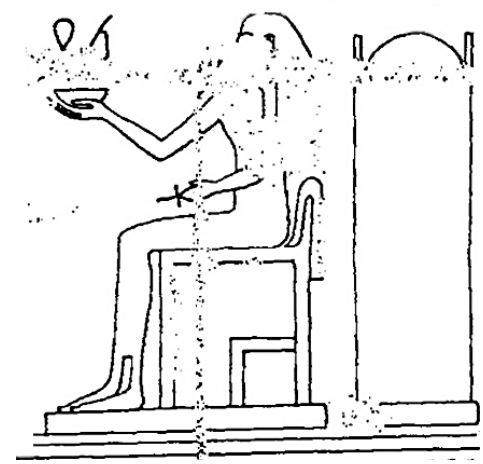

Medinet Habu V, The Temple Proper I, OIP 83, pl. 251.

\subsubsection{Standing, with no head-emblems}

During the reign of Ramses II at Karnak temples ${ }^{29}$, goddess Tjenenet was depicted standing, in adoring attitude (fig. 14, pl. 14), wearing a tri-partite hair wig and long, close-fitting tunic.

Fig. 14

Tjenenet standing in adoring attitude.

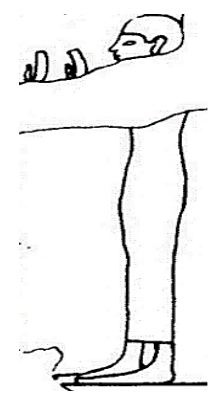

H.H Nelson, The Great Hypostyle Hall at Karnak, OIP 106, 1981, pl. 36 .

\subsubsection{Standing, wearing the vulture headdress.}

On Thutmoses III's Armant stela (JE 67377) ${ }^{30}$ in the Egyptian Museum, goddess Tjenenet is

and Chapels Adjoining the First Hypostyle Hall with Marginal Material from the Forecourts, OIP 83, pl. 251. ${ }^{29}$ G. Legrain, « Le logement et transport des barques sacrées et des statues des dieux dans quelques temples égyptiens», BIFAO 13, 1917, p. 42, pl. VI.2; P. Barguet, « Le temple d'Amon-Rê à Karnak. Essai d'exégèse », RAPH 21, 1962, p. 66; . Helck, « Ramessidische Inschriften aus Karnak. I. Eine Inschrift Ramses' IV », $Z \ddot{A} S$ 82, 1957, p. 134. W.J. Murnane, « The Earlier Reign of Ramesses II: Two Addenda », GM 19, 1976, p. 43.

30 For more information about this stela, see R. Mond, O.H Myers, Temples of Armant. A Preliminary Survey: The Text, 2 Bde, London, 1940, pp. 182-183; A. De 
depicted in fully-human manifestation, wearing the vulture-style headdress (fig. 15, pl. 15). She is standing at the back of King Thutmoses III, holding with her right hand his left hand, while she is raising her left hand upward

\section{Fig. 15}

Tjenenet wearing the vulture headdress, holding the hand of the King.

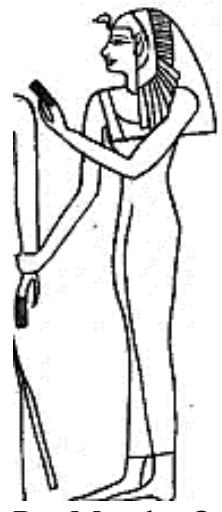

R. Mond, O. H. Myers, Temples of Armant. A Preliminary Survey, 2 Bde, London, 1940, pl. CIII.

\section{2..2.6. Standing, wearing Hathor Crown}

The wall reliefs of Medinet Habu ${ }^{31}$ temple hold many representations for goddess Tjenenet. She is represented as if she were identical to the goddess Hathor or Nehemt-away ${ }^{32}$. She is wearing the socalled Hathor Crown which is composed of the sun-disk, flanked by two cow horns, extended outwards. She is depicted standing after god Atum wearing Hathor Crown (fig. 16, pl. 16), holding the " $w 3 d$ " scepter and the " $n h$ " sign ${ }^{33}$. Furthermore, in another scene ${ }^{34}$, Tjenenet is standing (fig. 17, pl. 17), supporting god Khepry ${ }^{35}$. Moreover, in another scene ${ }^{36}$., she is represented standing behind god Montu, in adoring attitude (fig. 18, pl. 18), raising

Buck, Egyptian Reading book, Ares Publishers, Chicago, Illinois, 1948, pp.64-65; W. Helck, Urkunden der 18. Dynastie, Übersetzung zu den Heften, Akademie-Verlag, Berlin, 1984, pp. 12-14.

31 The temple of Medinet Habu is situated at the southern end of Luxor, on the western bank of the Nile. In ancient Egypt, it was a part of the $4^{\text {th }}$ Nome of Upper Egypt "W3st", and it was known with " $D_{3}-M w t$ " Meanwhile, in the ancient Greek, it was called " $\tau \grave{\alpha}$

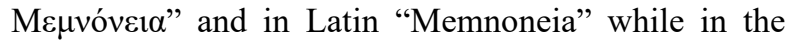
Coptic time, it was called "хнмє бнм" and nowadays, its modern name is "مدينة هابو" in Arabic.

32 The goddess Nehemt-away freely adopted the hathoric personal attributes for her own iconography her right hand upward, while with her left hand, she is holding the " $n h$ " sign.

\section{Fig 16}

Tjenenet standing, wearing Hathor Crown, and holding the "ws $\underline{d}$ " scepter.

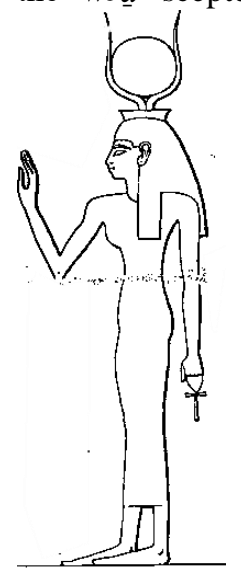

Medinet Habu: The Temple Proper III, Vol. VII, OIP 93, 1964, pl. 575.

\section{Fig 17}

Tjenenet standing, wearing Hathor Crown, and supporting god Khepry.

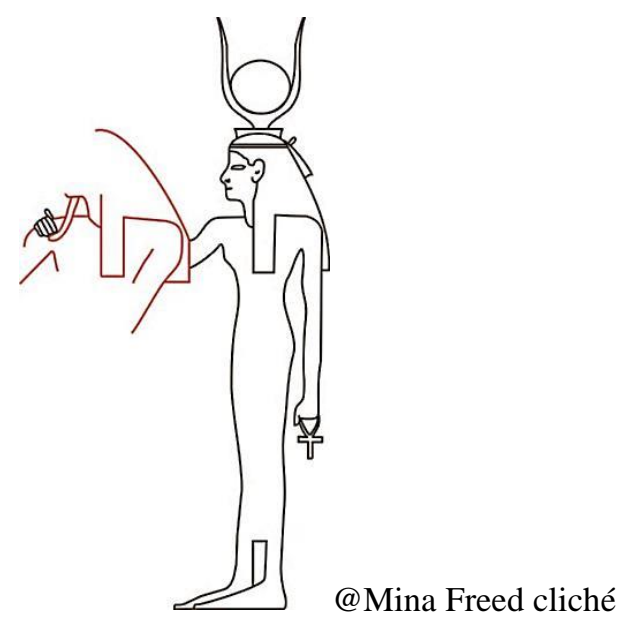

from the New Kingdom until the Hellenistic and Roman periods, see Shaikh Al arab, "The Adoption of Hathor's Personal Attributes for Nehemt-away's Iconography", ANKH 28/29 (2019/2020), pp. 44-77.

33 The Epigraphic Survey, Medinet Habu: The Temple Proper III, Vol. VII, OIP 93, 1964, pl. 575.

${ }^{34}$ Medinet Habu III, Vol. VII, OIP 93, pl. 585.

${ }^{35}$ For more information about Khepry, see $L G G \mathrm{~V}$, $718_{(\mathrm{a})}-720_{(\mathrm{c})}$; R. H Wilkinson, The Complete Gods and Goddesses of Ancient Egypt, Thames \& Hudson, 2003, pp. 230-233.

${ }^{36}$ Medinet Habu III, Vol. VII, OIP 93, pl. 583; G. Daressy, Notice Explictif des Ruines du Médinet Habou, 1897, p.197. 


\section{Fig 18}

Tjenenet standing, in adoring attitude, wearing Hathor Crown.

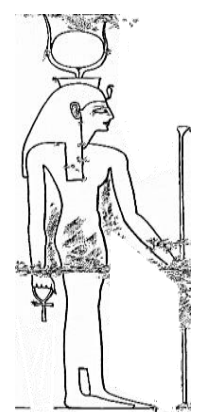

Medinet Habu: The Temple Proper III, Vol. VII, OIP 93, 1964, pl. 583.

\subsubsection{Enthroned, wearing a vulture headdress and Hathor Crown}

On the stela of Netery, the priestess of god Montu, which is housed nowadays in Petri Collection Museum (UC 14436) ${ }^{37}$, goddess Tjenenet-Rettawy is represented sitting on a low-back throne (fig. 19, pl. 19), receiving adoration from her. Remarkably, Tjenenet is wearing the vulture-style headdress over a tri-partite hair wig, with the crown of goddess Hathor which consists of the sun-disk, flanked by two horns of a cow, above all. Furthermore, she is wearing a long, close-fitting tunic and holding the " $w 3 \underline{d}$ " scepter and the " $n h$ " sign.

\section{Fig 19}

Tjenenet-Rettawy wearing the vulture headdress, and the Crown of Hathor.

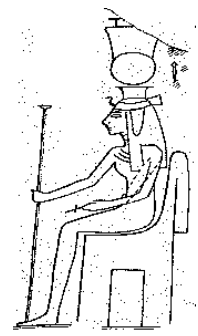

H.M Stewart, Egyptian Stelae, Reliefs, and Paintings: from the Petri Collection, I, pl. 34 (5).

2.2.8 Standing, wearing double feathers crown

${ }^{37}$ M. Stewart, Egyptian Stelae, Reliefs, and Paintings: from the Petri Collection, part I: the New Kingdom, $\mathrm{p}$. 44.

38 R. Bigler, B. Geige, "Eine Schenkungsstele Thutmosis' IV", Zeitschrift für Ägyptische Sprache und Altertumskunde, 121, 1994, pp.11-17.
On one of the donation stelae of the $18^{\text {th }}$ Dynasty, the stela ${ }^{38}$ of Medamoud that belongs to King Thutmoses IV, shows goddess Tjenenet-Rettawy exceptionally portrayed standing, wearing a Double- Feathers Crown fixed into a pedestal with a cobra on the forehead, and a long, tight tunic (fig. 20, pl. 20). She is raising her left hand upward, while with the right hand, she is holding the " $n h$ " sign.

\section{Fig. 20}

Tjenenet-Rettawy standing, wearing Double-Feathers Crown.

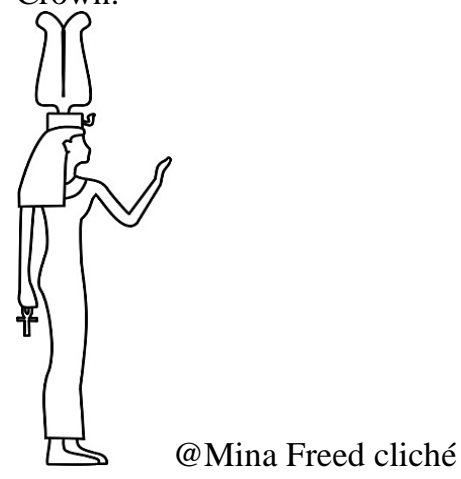

\subsubsection{Lioness-headed human form}

For the first time, during the $19^{\text {th }}$ Dynasty, the time of Ramses III, Tjenenet-Rettawy portrayed with the head of a lioness, surmounted by a sun-disk encircled by a cobra (fig. 21, pl. 21), on column $29^{39}$ of the west colonnade of Medinet Habu temple's second court. She is standing, wearing a long, tight tunic and holding the "wz $\underline{d}$ " scepter and the "enh" sign.

At the time of the $20^{\text {th }}$ Dynasty, On the stela of Raia $^{40}$, the chantress of Montu, in Florence Egyptian Museum, (Inv. 6390), the goddess Tjenenet is represented standing, in lioness-headed human form (fig. 21, pl. 22), holding the "wz ${ }^{\prime}$ " scepter and the "enh" sign.

\section{Fig 21}

Tjenenet-Rettawy in lioness-headed human form, with the sun-disk emblem, encircled by a cobra.

\footnotetext{
${ }^{39}$ The Epigraphic Survey, Medinet Habu: The Temple Proper II, VI, OIP 84, 1963, pl. 375.

${ }^{40}$ This stela dates back to the $20^{\text {th }}$ Dynasty of the New Kingdom, for further information about it, see $\mathrm{S}$. Bosticco, Museo Archeologico di Firenze. Le Stele egiziane del Nuovo Regno, Roma, 1965, Nr. 63.
} 


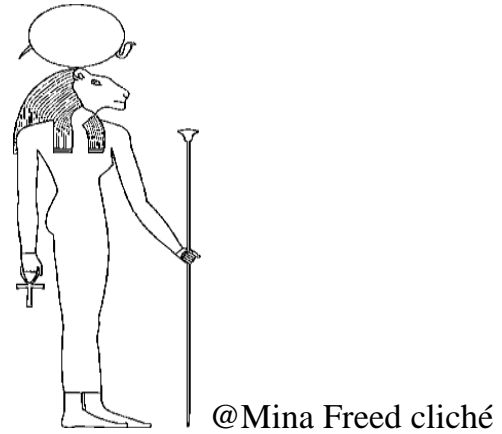

\subsubsection{Cobra-headed human form}

Once and for all, on the Chamber E's ceiling of the tomb $^{41}$ of Ramsses $\mathrm{VI}^{42}$ (KV9) at the Valley of the Kings, goddess Tjenenet $1 \theta_{1}$ the head of a cobra and the body of human (fig. 22, pl. 23), within the Seventh Hour of the Book of the Night $^{43}$. She is represented standing, wearing a tripartite hair wig and a long, close-fitting tunic ornamented with straps.

\section{Fig 22}

Tjenenet in cobra-headed form, standing with no head

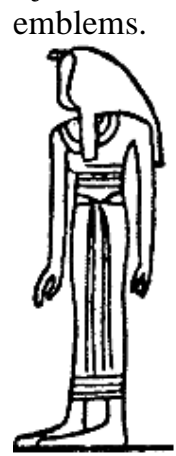

G. Roulin, Le Livre de la Nuit : Une composition égyptienne de l'au-delà II partie: Copie synoptique, 1996, pl. X (R VI b).

\subsection{The Iconography of Tjenenet during the Late Period}

Just two shreds of evidence can be traced for goddess Tjenenet during the Late Period. Although

${ }^{41} \mathrm{~K} . \mathrm{R}$. Weeks, the Illustrated Guide to Luxor: Tombs, Temples, and Museums, the American University in Cairo Press, 2005, pp.316-351; N. Reeves, R. H. Wilkinson, The Complete Valley of the Kings: Tombs and Treasures of Egypt's Greatest Pharaohs, Thames \& Hudson, 1996, pp. 164-165.

${ }^{42} L \ddot{A} \mathrm{~V}$, p. 124.

43 E. Hornung, The Ancient Egyptian Books of the Afterlife, trans. D. Lorton, London, 1999, pp. 122-123; G. Roulin, Le Livre de la Nuit: Une composition égyptienne de l'au-delà I partie: Traduction et the lack of resources at that time affected the process of studying Tjenenet iconography, adversely, yet the two scenes can tell about how did Tjenenet maintain her rank and role

\subsubsection{Standing, wearing a vulture headdress and} Hathor Crown

At the time of the $21^{\text {st }}$ Dynasty, precisely to the reign of king Herihor at Karnak temples, goddess Tjenenet is portrayed ${ }^{44}$ standing, wearing the socalled Hathor crown, which is composed of the sun-disk, flanked by two cow horns, extended outwards, over a vulture-style headdress with double heads of both the vulture and the cobra on her forehead (fig. 23, pl. 24). Furthermore, she is wearing a long, tight tunic, decorated with double wings and feathers. Moreover, she is holding the "ws $\underline{d}$ " scepter and the " $n h$ " sign.

\section{Fig. 23}

Tjenenet-Rettawy, standing wearing Hathor Crown of the vulture-headdress with two heads of the vulture and the cobra.

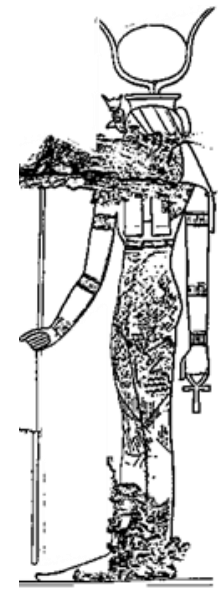

H.H Nelson, The Temple of Khonsu at Karnak, OIP 100, 1979, pl. 32.

\subsubsection{Enthroned, with no head-emblems}

In a relief ${ }^{45}$ that dates back to the $25^{\text {th }}$ Dynasty, to the reign of King Taharqa's birth at Karnak

commentaire; II partie: Copie synoptique, 1996, I: p. 212, II: p. 78, pl. X (R VI b).

44 E. Werner, The God Montu: From the Earliest Attestations to the End of the New Kingdom, UMI, 1988 , p. 215, p. 371, fig. 40; M. Bonhême, « Le Livre des Rois de la Troisième Période Intermédiaire. I. XXIe dynastie », BdE 99, 1987, pp. 54-55.; H.H Nelson, The Temple of Khonsu at Karnak, Volume 1. Plates 1-100, OIP 100, 1979, p. 16-17, pl. 32.

${ }^{45} \mathrm{M}$. Pillet, "Les scènes de naissance et de circoncision dans le temple nord-est de Moût, à Karnak" in ASAE 52, 
temples, the goddess Tjenenet appears within the Theban Ennead, enthroned with a half of a mantel only covers her body, reaching her thighs (fig. 24, pl. 25). She is wearing a tri-partite hair wig and holding the " $w 3 s "$ scepter with her right hand, while she extends her opened palm over her knees.

Fig. 24

Tjenenet, enthroned with no head-emblems.

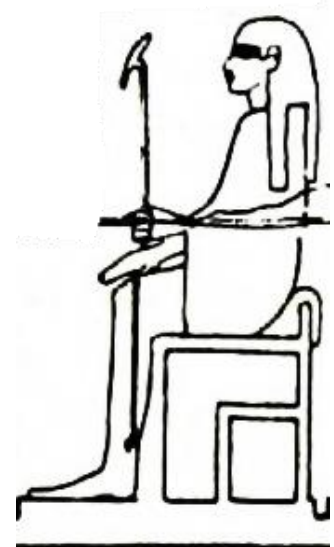

M. Pillet, "Les scènes de naissance et de circoncision dans le temple nord-est de Moût, à Karnak" in ASAE 52, 1952, fig.1. p. 78.

\section{Results and Discussion}

After this enumeration of Tjenenet's iconographical features from the Middle Kingdom to the Late Period, certain points are determined as follows. It is now evident that the study of Tjenenet's iconographical details is still in its beginnings. Further excavations, particularly in the areas around the principal cult centers of her divine consort (Montu) at Tod, Armant, and Medamoud, would inevitably increase the list of her images proposed here.

The first conclusion one can confidently reach is that Tjenenet's iconography remained with many variants throughout the centuries despite her relatively narrow theological profile. The Egyptians have always preferred to represent Tjenenet in a fully human form, from the Middle Kingdom to the Late Period. The other phenotypes of Tjenenet enriched her iconography; however, they have never replaced the standard representation. The Bicornuate-uterus-like crown or the two cow's horns with integrated sun disk were specific to Tjenenet, where they could

1952, pp. 78-79; F. Daumas, "Les Mammisis des Temples Égyptiens" in Annales De L'université De Lyon 32, Paris, 1952, pp. 46-47. become a key element and an identification index for the goddess, especially on appearing without inscription. Other crowns are considered less common and occur in specific contexts.

The study revealed that Tjenenet's hybrid forms are attested only in the New Kingdom.

The historical development of the cult of Tjenenet, especially from the New Kingdom, was characterized by such increasing associations with other deities, particularly Iunit and Rettawy. This partially contributed to her specific manifestations. Further, due to her association with the god Montu, Tjenenet gained some diffusion in terms of geographical distribution and semantic contexts as well.

Moreover, the occurrence and use of Tjenenet images seem not to be geographically restricted. Her traditional, main cult cities at Tod, Armant, and Medamoud revealed through the times several attestations. Nonetheless, the other cult centers also contributed to the list of Tjenenet's representations. As for the Egyptian deities in general, it is rather difficult to describe an exact profile of Tjenenet's iconography. The goddess can be closely associated with other deities, exchanging roles and attitudes. As shown above, according to the few attestations within the vast visual art of the Middle Kingdom, Tjenenet is only represented in anthropomorphic form as if she were similar to the goddesses Nekhbet by integrating their special iconographical elements into her own representations. In such forms, Tjenenet is indistinguishable Nekhbet and she can only be identified by the inscription accompanying her figures.

In the New Kingdom, Tjenenet obviously shares the characteristic personal iconographical elements which exclusively belong to the goddess Hathor, Sekhmet and Nehemt-away and her identification is only possible by means of inscriptions.

All in all, the personal attributes of Nekhbet, Meskhenet, Hathor or Nehemt-away are freely transferred to the goddess Tjenenet. Accordingly, it is virtually impossible to differentiate between her and these goddesses without inscription or archaeological context.

\section{Conclusion}


In conclusion, the Egyptians have always preferred to represent the goddess Tjenenet in a fully anthropomorphic form at least from the Middle Kingdom to the Late Period. It is significant to note that the representations of Tjenenet before the Middle Kingdom are unknown. The most popular depiction of Tjenenet is that of a standing or enthroned woman. However, her other phenotypes, which enriched her iconography, have never replaced the standard representation. The Bicornuate-uterus-like crown was specific to Tjenenet; it is a key element and an identification index for the goddess, especially on appearing without inscription. Other crowns are considered less common and occur in specific contexts.

In brief, dotted with characteristic iconographical features of Hathor, Nehemt-away, Nekhbet, or Meskhenet was theologically invented at least from the Middle Kingdom to the fitting counterpart or female double of Montu. Without inscriptions, her Bicornuate uterus or archaeological context, it is nearly impossible to distinguish Tjenenet from Hathor, Nehemt-away, Nekhbet, or Meskhenet. As a goddess of birth and motherhood, her iconography was affected starting from the New Kingdom, as she started to bear the cow uterus as her emblem. Moreover, being the counterpart of Montu-Re, and her blending with goddess Rettawy, Tjenenet obtained the solar nature, bearing the crown of Hathor.

The representations of goddess Tjenenet could be a dating key, where in the Middle Kingdom she did not obtain any head emblems but the vulture headdress. Meanwhile, starting from the New Kingdom, she obtained the distinctive Bicornuate uterus, Hathor crown, Double Feathers crown.

\section{References}

A. Oppenheim, D. Arnold, K. Yamamoto, Ancient Egypt Transformed the Middle Kingdom, The Metropolitan Museum of Art, New York, 2015

Ch. Thiers, "Hymne à la déesse Tanent et présence latopolite sur quelques blocs d'Ermant", in: CENiM 13, 2015, pp.295-326

E. K. Werner, The God Montu: From the Earliest Attestations to the End of the New Kingdom, Ph. D. Dissertation, Yale University, 1985

The Epigraphic Survey, Reliefs and Inscriptions at Karnak - Volume I. Plates 1-78. Ramses III's Temple within the Great Inclosure of Amon, Part I, OIP 25, 1936.

F. Bisson de la Roque, Tôd, FIFAO 17, 1937.
Fr. Burgos, Fr. Larché, La Chapelle Rouge. Le sanctuaire de barque d'Hatshepsout, I, Paris, 2006.

G. Legrain, "La litanie de Ouasit ", ASAE 15, 1915, p. 278.

G. Roulin, Le Livre de la Nuit: Une composition égyptienne de l'au-delà I partie: Traduction et commentaire; II partie: Copie synoptique, 1996.

H. Gautheir, Dictionnaire des noms géographiques contenus dans Les texts Hiéroglyphiques I, 1929.

H. M. Stewart, Egyptian Stelae, Reliefs, and Paintings: from the Petri Collection, part I: the New Kingdom, 1976.

H.H Nelson, The Temple of Khonsu at Karnak, Volume 1. Plates 1-100, OIP 100, 1979.

I. Rosellini, I Monumenti dell' Egitto e della Nubia, Tomo III, Parte I, Pisa, 1838

K. A. Kitchen, Ramesside Inscriptions: Historical and Biographical III, Oxford Blackwell Ltd, 1980

K. Sethe, Urkunden der 18. Dynastie, Abteilung IV, Leipzig, 1906, p. 556; R. Lepsius, Denkmäler aus Aegypten und Aethiopien Text, III, Leipzig, 1900

L. Christophe, "Temple d'Amon à Karnak. Les divinités des colonnes de la grande salle hypostyle et leurs épithètes", in: BdE 21, 1955, p. 17.

M. Bonhême, "Le Livre des Rois de la Troisième Période Intermédiaire. I. XXIe dynastie », BdE 99, 1987.

M. Pillet, "Les scènes de naissance et de circoncision dans le temple nord-est de Moût, à Karnak" in ASAE 52, 1952, pp. 78-79.

M. Thersia, Synkretismus in Ägyptischer Ikonographie die Göttin Tjenenet, Otto Harrassowitz, 1979.

M.-A. Bonhême, Une chapelle d'Hatshepsout à Karnak, I, Le Caire, 1977.

O. Berlev, S. Hodjash, Catalogue of the Monuments of Ancient Egypt: From the Museums of the Russian Federation, Ukraine, Bielorussia, Caucasus, Middle Asia and the Baltic States, 1998.

P. Barguet, Le Temple d'Amon-Rê à Karnak: Essai d' exégèse, le Caire, 1962.

R. H. Wilkinson, The Complete Gods and Goddess of Ancient Egypt, Thames \& Hudson, 2003.

R. Mond, O.H Myers, Temples of Armant. A Preliminary Survey: The Text, 2 Bde, London, 1940.

S. Bosticco, Museo Archeologico di Firenze. Le Stele egiziane del Nuovo Regno, Roma, 1965

Shaikh Al arab, "The Adoption of Hathor's Personal Attributes for Nehemt-away's Iconography", ANKH 28/29 (2019/2020), pp. 44-77.

The Goddess Iwnj.t", in Association of Arab Universities For Tourism and Hospitality, JAAUTH, Vol.4. No 2, pp. 123-149.

W.J. Murnane, Ramesses I and the Building of the Great Hypostyle Hall Revisited, VA 10/2-3, 1997. 
Plates

Pl. 1

Tjenenet blessing Mentuhotep III.

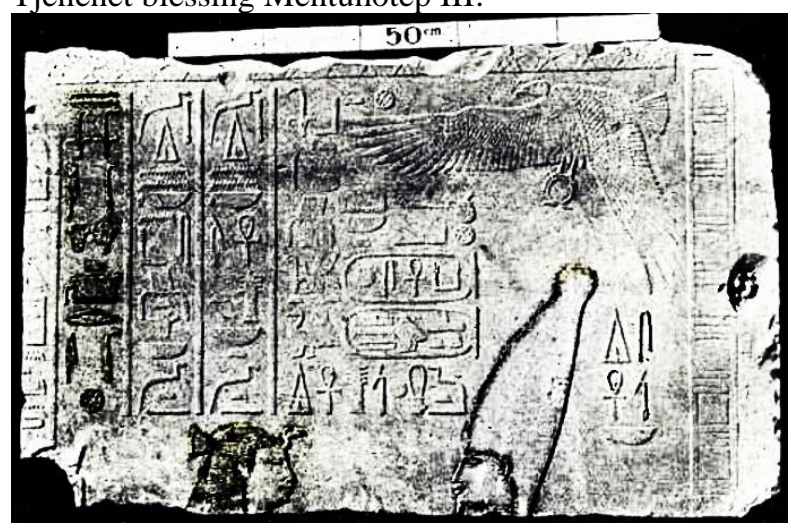

F. Bisson de la Roque, Tôd, FIFAO 17, 1937, fig. 38.

Pl. 3

Tjenenet providing Montuhotep III with offerings and provisions.

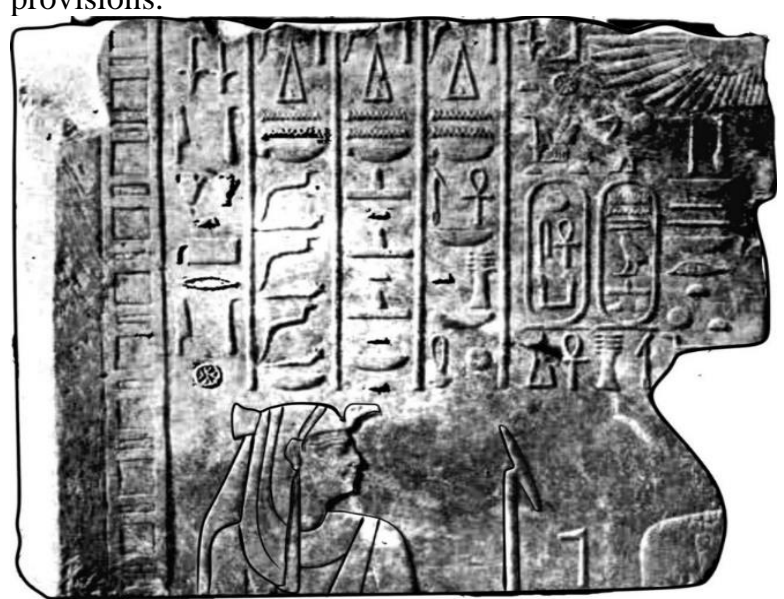

F. Bisson de la Roque, Tôd, FIFAO 17, 1937, fig. 41.

Pl. 5

The coronation of Thutmoses III by Montu with his consort Tjenenet-Rettawy.

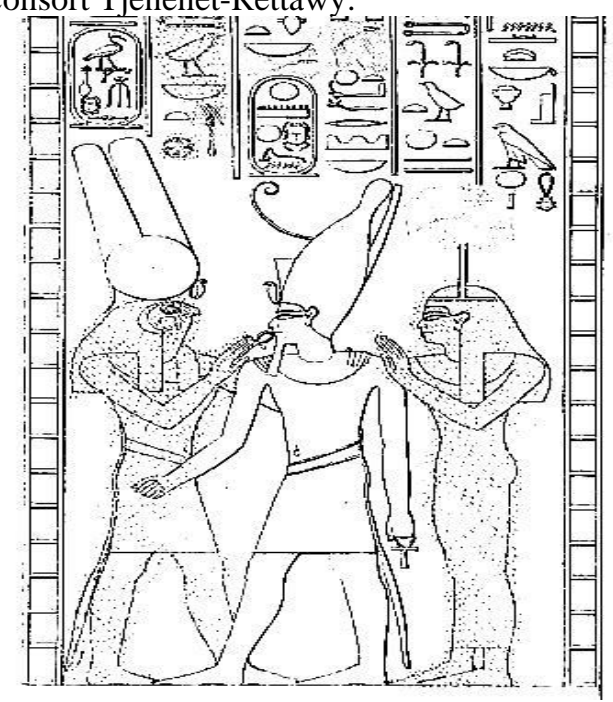

$L D$ III, 34a.
Pl. 2

Mentuhotep III's coronation by Tjenenet and Montu.

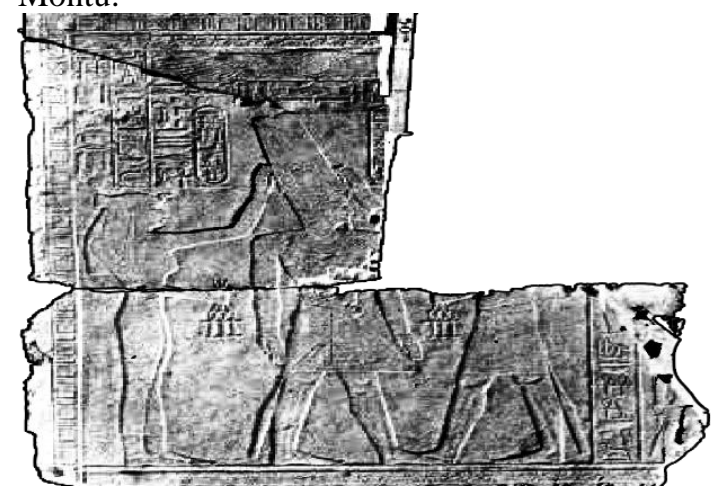

Bisson de la Roque, Tôd, FIFAO 17, 1937, fig. 32.

\section{Pl. 4}

Hatshepsut offering two $n w$-jars to Hathor in the presence of Tjenenet-Rettawy.

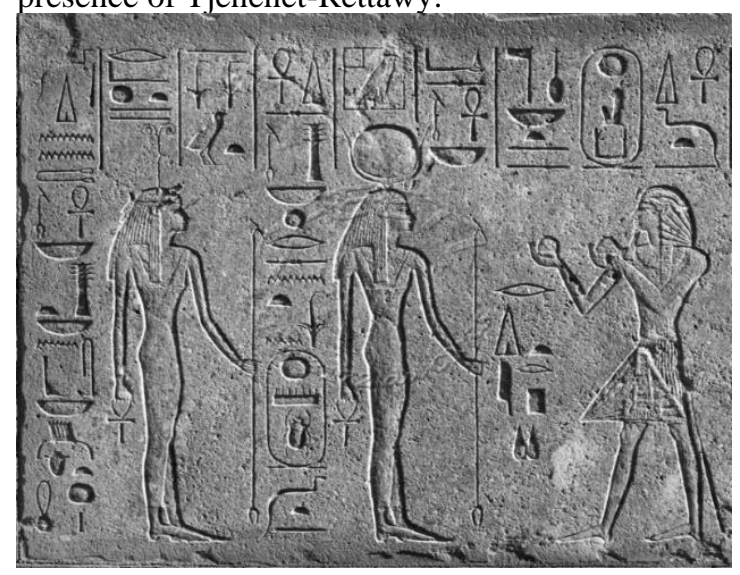

http://www.cfeetk.cnrs.fr/archives/?n=138053 accessed on 24 February 2020.

Pl. 6

Ramses I Greeting with the Nemset-vase god Sobek-Re in the presence of Tjenenet.

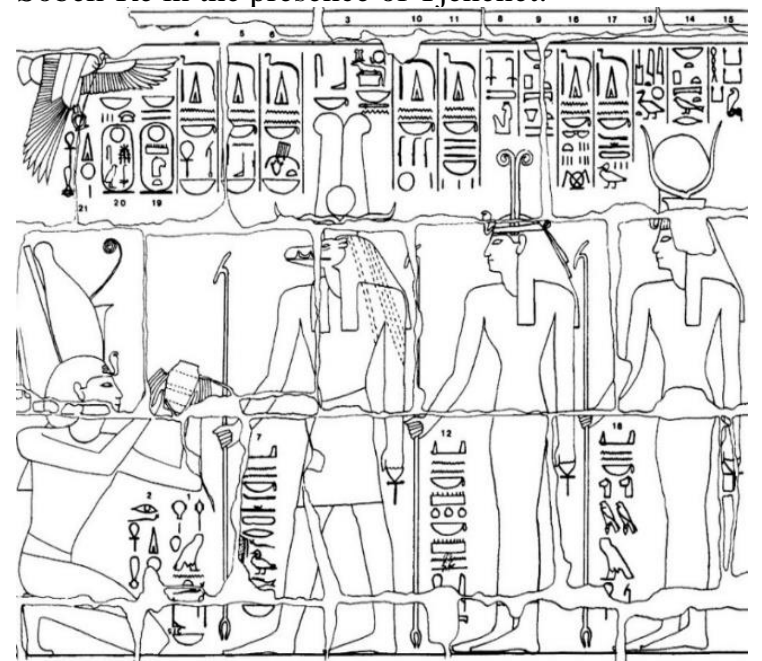

H.H Nelson, The Great Hypostyle Hall at Karnak, OIP 106, 1981, pl. 140. 
Pl.7

Ramses II offering incense to Sobek-Re, Tjenenet, Rettawy, and Hathor.

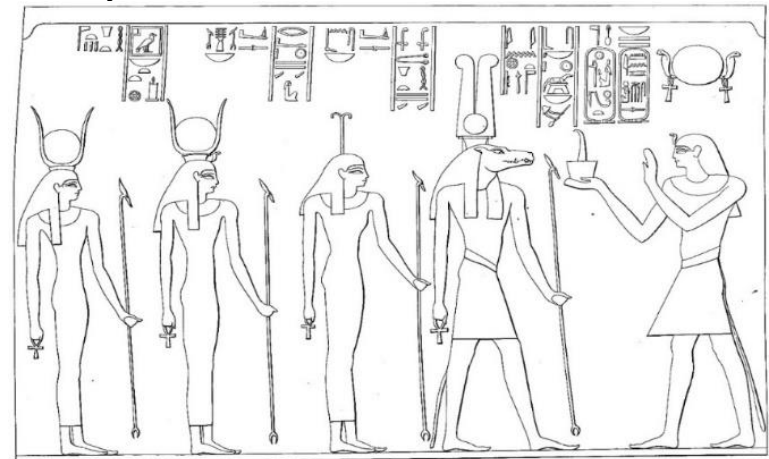

I. Rosellini, I Monumenti dell' Egitto e della Nubia, III, 1838, pl. XXXI (2).

PI. 9

Ramesses IV offering an ointment to god Montu in the presence of goddess Tjenenet.

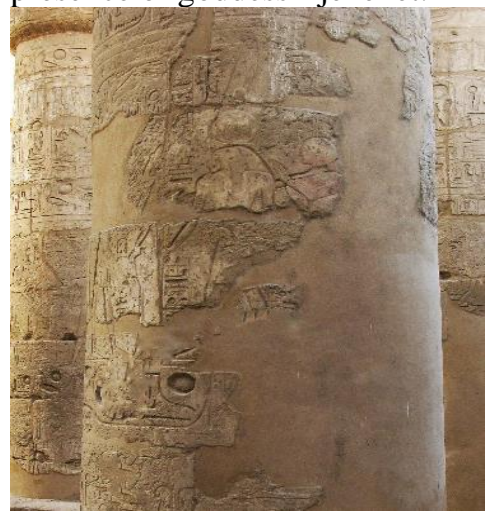

http://www.cfeetk.cnrs.fr/archives/? $n=168997$ accessed on 24, March 2020.

Pl. 11

Tjenenet within the Theban Ennead beholding the Sed festival of Thutmoses III

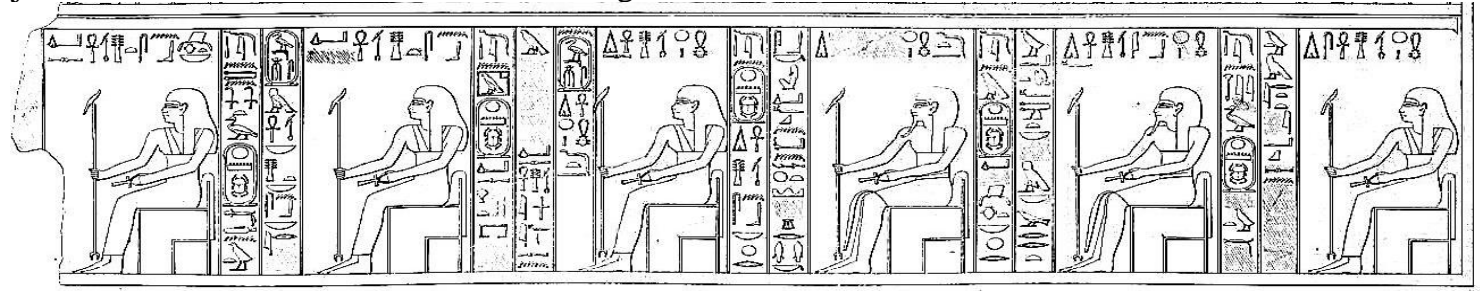

$L D$ III, 34d.

Pl. 12

Tjenenet sitting as a part of a Tetrad.

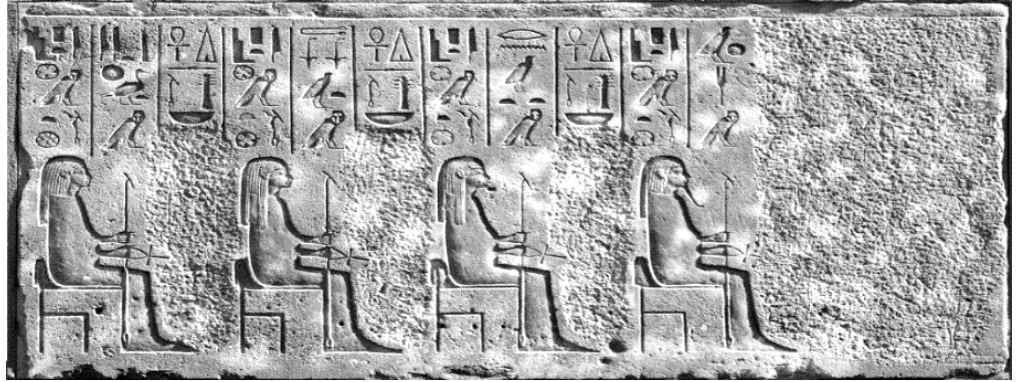

http://www.cfeetk.cnrs.fr/archives/?n=76860, accessed on 24 February 2020. 
Pl. 13

Tjenenet before her shrine granting favours to Ramsses III.

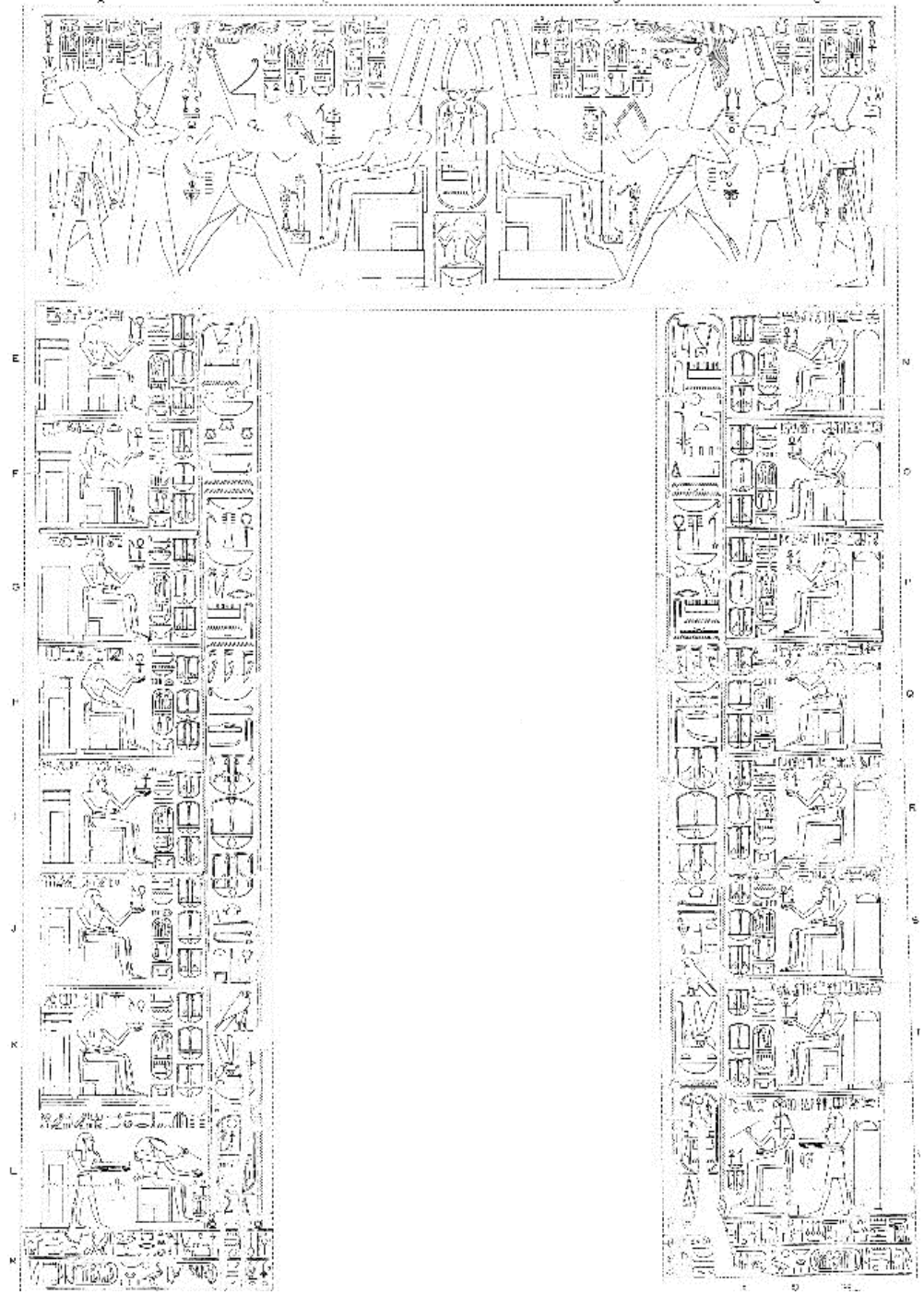

Medinet Habu V, The Temple Proper I, OIP 83, pl. 251.

Pl. 14

Ramses II and the Great Ennead of Karnak are adoring the Theban Triad.

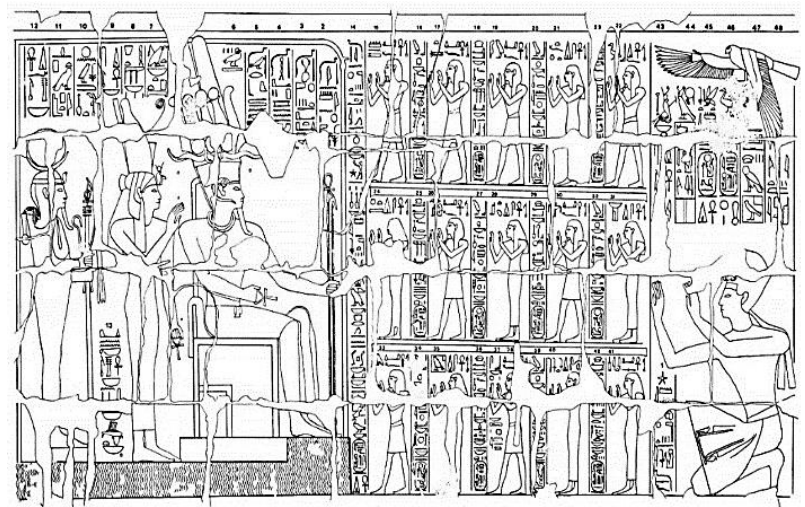

H.H Nelson, The Great Hypostyle Hall at Karnak, OIP 106, 1981, pl. 36.
Pl. 15

Thutmoses III praising God Montu in the presence of Tjenenet, four times.

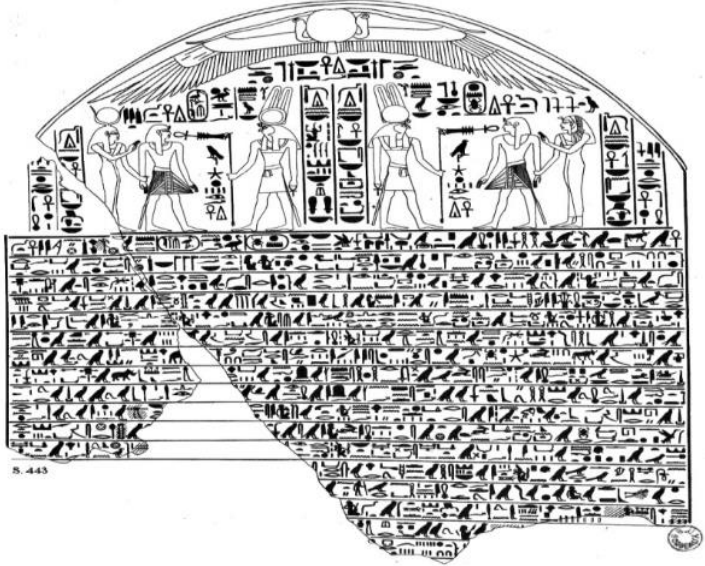

R. Mond, O.H Myers, Temples of Armant. A Preliminary Survey, 2 Bde, London, 1940, pl. CIII. 
Pl. 16

Ramsses III presenting wine to Atum of Tod with Tjenenet.

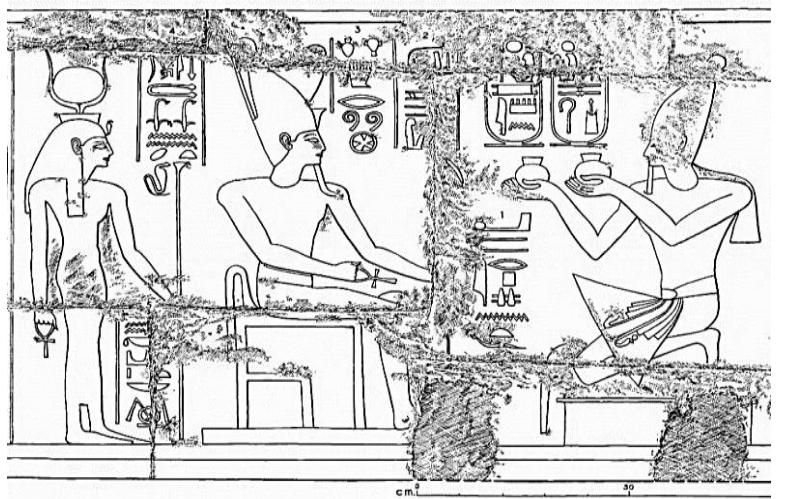

The Epigraphic Survey, Medinet Habu: The Temple Proper III, OIP 93, 1964, pl. 575.

PI. 18

Ramses III offering wine to Montu in the presence of Tjenenet.

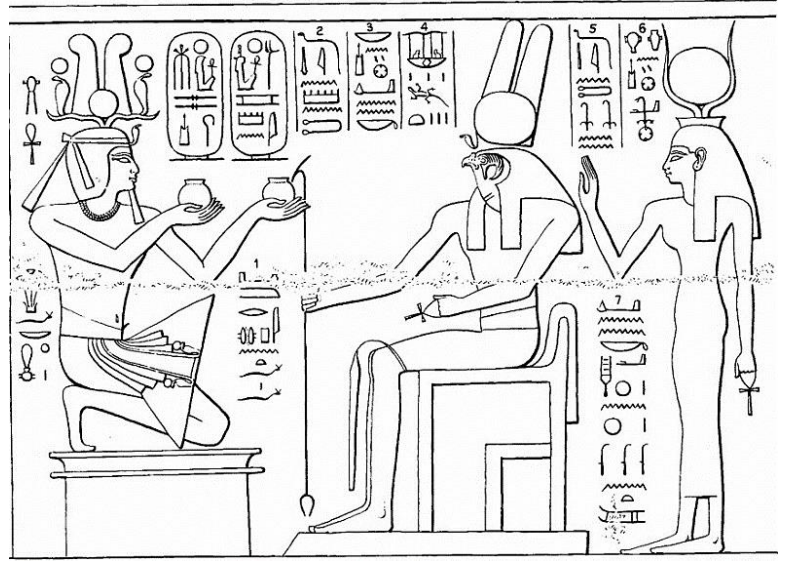

The Epigraphic Survey, Medinet Habu: The Temple Proper III, OIP 93, 1964, pl. 583.

Pl. 20

Thutmoses IV praising God Montu in the presence of Tjenenet-Rettawy.

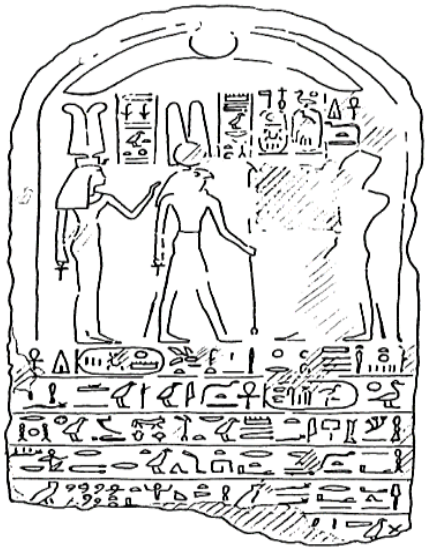

R. Bilger, B.Geiger, 'Eine Schenkungsstele Thutmosis' IV",ZÄS 121,1994, p.12.

Pl. 22
Pl. 17

Ramsses III offering ointment to Khepry in the presence of Tjenenet.

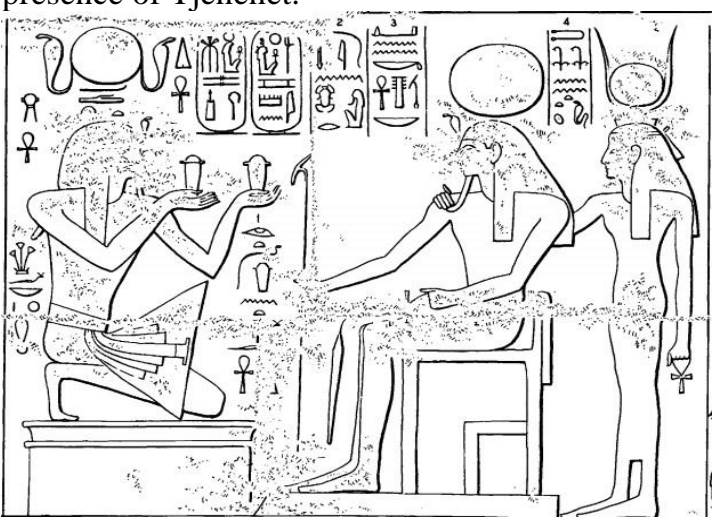

The Epigraphic Survey, Medinet Habu: The

Temple Proper III, OIP 93, 1964, pl. 585.

Pl. 19

The Priestess Netery adoring goddess TjenenetRettawy.

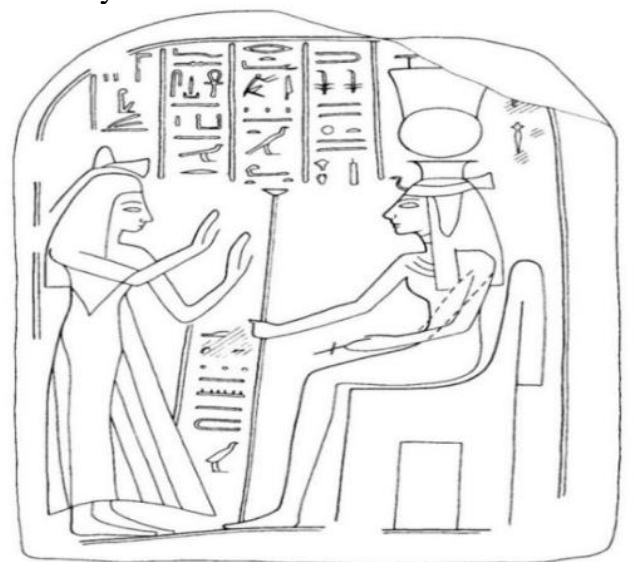

H.M Stewart, Egyptian Stelae, Reliefs, and Paintings: from the Petri Collection I, pl. 34 (5).

\section{Pl. 21}

Ramses III presenting libation to Montu with his consort Tjenenet-Rettawy.

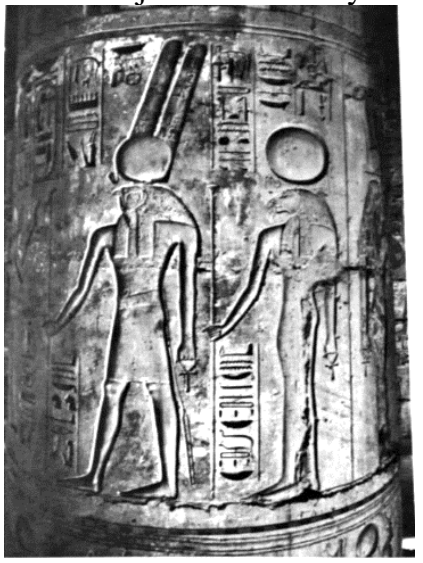

The Epigraphic Survey, Medinet Habu: The Temple Proper VI, OIP 84, 1963, pl. 375.

Pl. 23 
Raia playing "sššt" sistrum before Tjenenet-Rettawy.

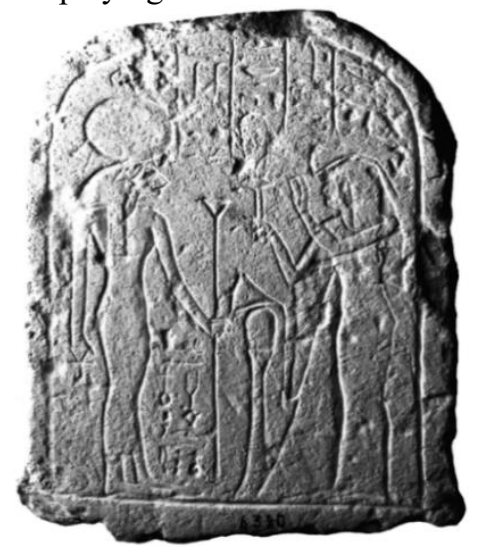

Bosticco, Museo Archeologico di Firenze. Le Stele egiziane del Nuovo Regno, Roma, 1965, Nr. 63.

\section{Pl. 24}

Herihor is offering Bouquets to god Montu in the presence of goddess Tjenenet-Rettawy.

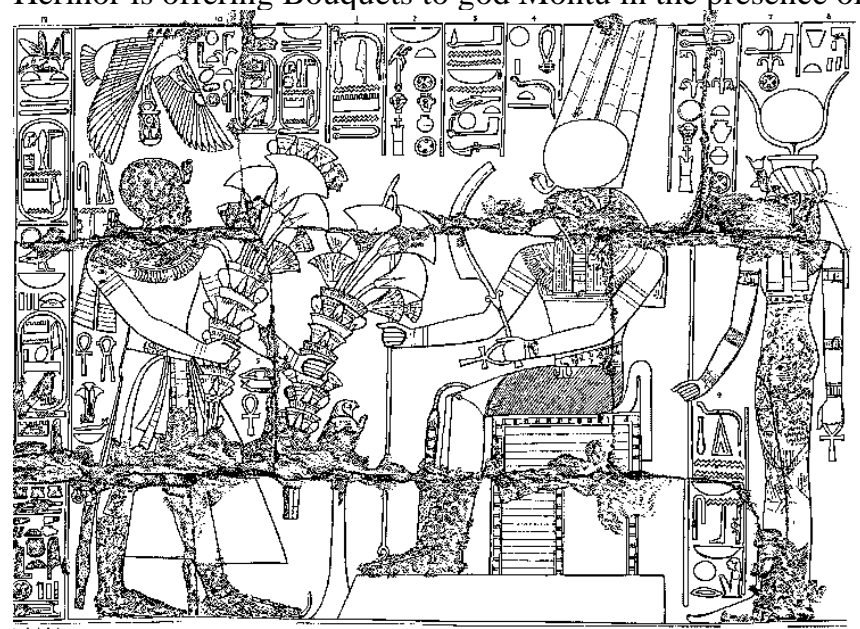

H.H Nelson, The Temple of Khonsu at Karnak, OIP 100, 1979, pl. 32.

Pl. 25

Taharqa's birth scene along the Theban Ennead in the presence of Tjenenet.

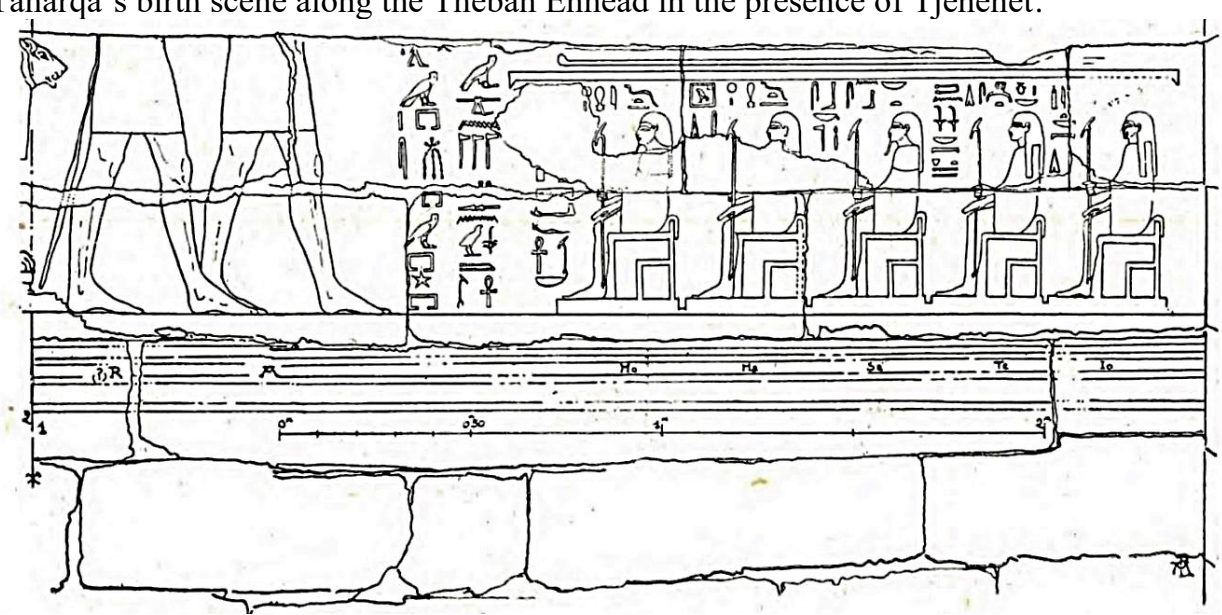

M. Pillet, "Les scènes de naissance et de circoncision dans le temple nord-est de Moût, à Karnak" in ASAE 52, 1952, fig.1. p. 78.
Tjenenet with cobra head within the Seventh Hour of the Book of the Night.

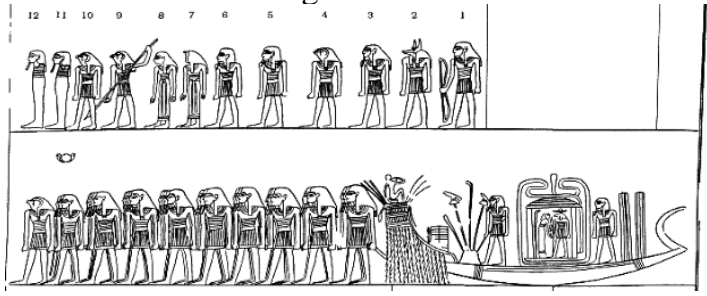

G. Roulin, Le Livre de la Nuit: Une composition égyptienne de l'au-delà II partie: Copie synoptique, 1996, pl. X (R VI b). 